\title{
OPPORTUNITIES AND CHALLENGES FOR SUSTAINABLE SHEEP PRODUCTION IN SERBIA
}

\author{
M. P. Petrović ${ }^{1}$, M. M. Petrović ${ }^{1}$, D. Ružić-Muslić ${ }^{1}$, V. Caro-Petrović, N. \\ Maksimović ${ }^{1}$, Z. Ilić ${ }^{2}$, S. Vučković ${ }^{3}$ \\ ${ }^{1}$ Institute for Animal Husbandry, Belgrade-Zemun, Republic of Serbia \\ ${ }^{2}$ Faculty of Agriculture, Lešak, Republic of Serbia \\ ${ }^{3}$ Faculty of Agriculture, Belgrade-Zemun, Republic of Serbia \\ Corresponding author: milanppet@yahoo.com \\ Invited paper
}

Abstract: This paper analyzes the present state of sheep farming in Serbia and provide guidance for sustainable development in the future. It also discusses the challenges of the modern age that may affect the viability of sheep production. Today in Serbia grows less than 1.5 million sheep. In terms of breed structures, most of the population makes indigenous Pramenka sheep $(80 \%)$, while the remaining 20\% are: Tsigai, Merinolandschaf, Ile de France, Pirot improved, Mis sheep, and other less important population, as well as the crossbreed with foreign and local domestic sheep. However, due to the intense process of industrialization, from the second half of the twentieth century until today there is a trend of depopulation, demographic discharge of the village, which has resulted in reducing the farms so that the number of sheep in the past two decades fell by about $30 \%$. The greatest reduction in the number of sheep registered in the nineties. After stabilization, a large decrease in the number of sheep was followed by the 2010th year and by $6 \%$ compared to 2008 year. Genetical improvement is significantly increased level of production of all species of domestic animals. However, animals selected for high and efficient production are exposed to greater risk. This primarily refers to the physiological and immunological problems, but would generally be said that all this leads to distortion of harmony between the organism and the environment and the repercussions on the molecular level. Sustainable development of sheep breeding in Serbia must be kept in mind this reality. New challenges facing the sheep breeding of Serbia, stems from a political orientation toward membership in the European Union. Sheep Serbia must find its place in this new challenge. breeding

Key words: sheep, sustainable production, genetical improvement, sheep 


\section{Introduction}

Sheep breeding is an important area of the economy, because the breeding of sheep, get valued products, even those using the natural resources where human feet rarely goes down. Integrating sheep into a farming operation can contribute to the economic and environmental sustainability of the whole farm. The relatively small investment required, and the gradually increasing size of the flock, make sheep production a good choice for the beginning small-scale or part-time farmer. For the established farmer seeking to diversify, sheep offer a number of benefits (Darcy, 1995; Serradilla, 2002; Wells et al., 2000; Mason, 2003; Petrović, 2007). Sustainable sheep farming is a way to get high quality meat, milk and wool, while preserving the environment, respect for labor and welfare in order to achieve economic gains and increased social status of farmers.For sustainable sheep production in today's conditions, it is necessary to know a number of biological, technological, organizational and market factors (Petrovic, 2007). If farmers want to increase their production and profit they need to apply modern methods of selection (Petrovic, 2000; Notter 2001; Snowder, 2002; Hanford et al., 2002, 2003 , 2005; Ugarte, 2007; Teneva, 2009). For success in sustainable sheep production many factors have an impact: effectiveness of controls and recording production characteristics, evaluation of genetic parameters and value of animals and organization of the diffusion of genetic material. (Petrovic et al, 2009; de Vries et al., 2004; Safari et al., 2005).

The European landscape is characterised by a range of diverse farming systems. These relate not only to varied geographical environments, but also to different social and cultural environments for farming and food production. This diversity is unique to Europe and underlines the importance of European agriculture. Increased demand for a plentiful supply of cheap food that also maintains a diverse and sustainable supply represents a challenge for traditional agricultural systems. In the field of livestock farming, demands for high welfare production systems and the maintenance of landscapes in the face of outbreaks, or the fear of outbreaks, of animal disease and of increasing international competition, threaten the European model of agriculture (Neeteson et al., 2006). Sheep is a significant sector of livestock production in the Serbia especially in the mountainous area, which has significant natural resources (Petrovic, 2010). Out of 826,834 ha of grassland and 601,152 ha meadow in Serbia, about $86 \%$ are located in mountain area where is about $50 \%$ of the rural population. However, due to the intense process of industrialization, from the second half of the twentieth century until today there is a trend of depopulation, demographic discharge of the village, which has resulted in reducing the number of sheep. The aim of this paper is to review the status of our sheep production in Serbia and point to the possibility of sustainable development in the future. 


\section{The situation of sheep production}

Over $90 \%$ of the sheep in Serbia is concentrated in small breeders, with the variable structure and size of the herd. In the last twenty years have seen a change in the numbers of sheep, as Table 1 shows.

Table 1. The numbers of sheep in Serbia (000 head)

\begin{tabular}{|l|c|c|c|c|c|c|c|}
\hline Year & 1990 & 2000 & 2005 & 2006 & 2007 & 2008 & 2010 \\
\hline Sheep & 2.127 & 1.611 & 1.576 & 1.556 & 1.606 & 1.605 & 1.475 \\
\hline Index & 100 & 76 & 74 & 73 & 75 & 75 & 69 \\
\hline
\end{tabular}

From the above table can see that the number of sheep in the past two decades fell by about $30 \%$. The greatest reduction in the number of sheep registered in the nineties. After stabilization, a large decrease in the number of sheep was followed by the 2010th year and by $6 \%$ compared to 2008 year. Thus, today in Serbia grows less than 1.5 million sheep. In terms of breed structures, most of the population makes indigenous Pramenka sheep (80\%), while the remaining 20\% are: Tsigai, Merinolandschaf, Ile de France, Pirot improved, Mis sheep, and other less important population, as well as the crossbreed with foreign and domestic sheep._In Serbia sheep production, for the last few decades, there have been a certain changes in the system of breeding. Improved the conditions of keeping feeding and care. Also imported of foreign breeds, and some of them adapted to new conditions, are grown in pure breed. Finally, obtained the new domestic more productive breed: Miss sheep and Pirot improved population, which should have an important role in the future. Genetic improvement of sheep in Serbia is carried out in accordance with the breeding program. This program covers the most important breed of sheep that are of national interest. The most important average production parameters of the population covered by the breeding program are given in Table 2 . 
Table 2. Average (LSM $\pm \mathrm{SE}$ ) values and production traits of sheep breeds in Serbia (Petrovic et al., 2010)

\begin{tabular}{|l|c|l|l|l|l|l|}
\hline \multirow{2}{*}{$\begin{array}{l}\text { Breed of } \\
\text { sheep }\end{array}$} & $\begin{array}{c}\text { Fertility, } \\
\%\end{array}$ & \multicolumn{2}{|l|}{ Body weight of lambs, kg } & $\begin{array}{l}\text { Weight of } \\
\text { adult } \\
\text { animals, kg }\end{array}$ & $\begin{array}{l}\text { Yield of } \\
\text { wool, kg }\end{array}$ \\
\cline { 3 - 7 } & & 1 day & 30 days & 90 days & \\
\hline $\begin{array}{l}\text { Merinoland- } \\
\text { schaf }\end{array}$ & 118 & $3.83 \pm 0.13$ & $12.89 \pm 0.34$ & $28.78 \pm 0.99$ & $57.13 \pm 2.41$ & $3.31 \pm 0.05$ \\
\hline $\begin{array}{l}\text { Pirot } \\
\text { Improved }\end{array}$ & 127 & $3.17 \pm 0.10$ & $11.86 \pm 0.40$ & $24.22 \pm 1.01$ & $59.13 \pm 2.86$ & $2.58 \pm 0.07$ \\
\hline Ile de France & 132 & $4.61 \pm 0.16$ & $14.94 \pm 0.33$ & $33.96 \pm 0.90$ & $69.57 \pm 2.99$ & $3.87 \pm 0.06$ \\
\hline Mis Sheep & 173 & $4.07 \pm 0.10$ & $12.12 \pm 0.35$ & $34.34 \pm 0.95$ & $71.87 \pm 3.01$ & $3.96 \pm 0.05$ \\
\hline $\begin{array}{l}\text { Sjenica } \\
\text { Sheep }\end{array}$ & 129 & $3.09 \pm 0.09$ & $11.82 \pm 0.42$ & $21.16 \pm 0.95$ & $57.98 \pm 2.11$ & $2.32 \pm 0.04$ \\
\hline $\begin{array}{l}\text { Svrljig } \\
\text { Sheep }\end{array}$ & 133 & $3.38 \pm 0.11$ & $10.56 \pm 0.31$ & $26.66 \pm 0.98$ & $54.53 \pm 2.13$ & $2.82 \pm 0.09$ \\
\hline $\begin{array}{l}\text { Lipska } \\
\text { Sheep }\end{array}$ & 127 & $3.90 \pm 0.14$ & $13.61 \pm 0.38$ & $28.57 \pm 0.96$ & $62.48 \pm 2.27$ & $3.51 \pm 0.06$ \\
\hline $\begin{array}{l}\text { Krivovir } \\
\text { Sheep }\end{array}$ & 140 & $3.36 \pm 0.10$ & $8.70 \pm 0.28$ & $20.70 \pm 1.03$ & $54.80 \pm 2.17$ & $2.33 \pm 0.03$ \\
\hline
\end{tabular}

In Table 2 we can see that Mis population had the highest fertility and the highest body weight of lambs at 90 days, while the results of body weight of lambs at birth and the age of 30 days were greatest at Ile de France. In terms of weight of adult animals are superior Mis sheep. With regard to yield of wool the highest value are recorded in Mis population, while the smallest weight was Sjenica breed. Krivovir breed showed the lowest value of the body weight of lambs at 30 and 90 days. Similar results of these studies stated by Petrović (1992, 2006; Petrovic et al., 2009) and Mekić (1994). Lower values for body weight of lambs of Sjenica population were obtained by Mekić at al. (2008), which indicates that there are differences within one system of rearing which are mainly consequence of nutrition.

The following results can be seen in Table 3 which shows the production of meat and milk of sheep in Serbia. We can also see on the said table that the production of sheep meat per year varies, but in addition to reducing the number of heads, gave the same value as the beginning of the ninth decade. This is the result of genetic improvement of populations, and improved growing conditions. Milk production has declined by $50 \%$ due to the reduced number of sheep in Serbia, but also because of the absence of selection for milk yield. This is because the production of meat is given far more attention. 
On the other hand it is a loss, because Serbia has previously produced and exported large quantities of sheep cheese, especially Pirot cheese-kachkaval (Petrović et al., 2008).

Table 3. Sheep meat and milk production in Serbia

\begin{tabular}{|l|c|c|c|c|}
\hline Year & Meat (000 tons) & Index & Milk (million liters) & Index \\
\hline 1990 & 23 & 100 & 20 & 100 \\
\hline 2000 & 19 & 82 & 19 & 95 \\
\hline 2005 & 21 & 91 & 16 & 80 \\
\hline 2007 & 20 & 86 & 15 & 75 \\
\hline 2008 & 23 & 100 & 14 & 70 \\
\hline 2009 & 25 & 109 & 14 & 70 \\
\hline 2010 & 23 & 100 & 10 & 50 \\
\hline
\end{tabular}

\section{Sustainable Sheep Production}

Regardless of the motives behind the desire to deal with breeding sheep for a successful business in the sheep the same rules, namely: The right choice of direction and production systems; production must always be kept under control; sheep breeding technique is constantly improving; the animals must be treated humanely.The most common mistakes made by breeders of sheep in Serbia are the following:

Lack of clear purpose of production; production is carried out randomly; misconceptions about the real quality of their own heads;

lack of production records; lack of desire for improvement and increase of production; poor marketing approach. conditions:

To achieve high production farmer per head has to provide several

Good genetically potential his sheep; high percentage of conception sheep (90-95\%); high fertility ewes (140-160\%); the low mortality rate of lambs (less than $8 \%$ ); good quality products.

The first condition is breed and their genetic potential. There is often mistaken that buying a thorough bred solve everything and put an end to further concern about the success of production. If so, would not talk that the breed only "genetic potential". What does this mean? Breeds will bring out their potential as much as we might be able to handle it. For example, the same breed can have 20$30 \%$ higher or lower values of conception, fertility, mortality, quality of products. It all depends on us and our knowledge with regard to it is our earnings as the 
ultimate goal of production. Maintaining the quality of the herd, is achieved by applying different methods of farming.

That is a system of measures to increase productivity of sheep, so each method of sheep breeding must have a clearly defined goal. In doing so, one must take into consideration the particular conditions of production and environmental effects. For example, not all the same whether the farm is situated in Vojvodina plain, or the Stara Planina mountain. Second, a condition that can not be ignored, the market (Wells et al., 2000). We know that some countries, importers of lamb, with interest only for the lambs to $25 \mathrm{~kg}$ live weight. But many countries, especially from the Arab world, higher prices lambs over $30 \mathrm{~kg}$. There are two basic methods of breeding sheep in Serbia: breeding of pure breed and crossbreeding. Both systems are represented, but the system crossing is particularly evident on the farms where the main orientation of lambs for meat production. When it comes to developing a sustainable sheep production in Serbia, it should be remembered above all a healthy and safe food. In order to achieve this it is important to develop such technologies that will not threaten the biological status of sheep that are grown.

Serbia is known as not polluted environment. In the sheep breeding should be shown the most natural way, without modern genetic manipulation, because large manipulation can carry great risks.

\section{Challenges and risks in the future}

Genetical improvement is significantly increased level of production of all species of domestic animals (Petrovic, 2000; Hanford et al., 2005). However, animals selected for high and efficient production are exposed to greater risk. This primarily refers to the physiological and immunological problems, but would generally be said that all this leads to distortion of harmony between the organism and the environment and the repercussions on the molecular level. Examples of this are presented in the numerous scientific publications, especially during the last decade (Teneva, 2009; Teneva and Petrovic 2010; Taberlet et al., 2011). Biological explanation for the occurrence of adverse effects of selection is presented. Selection may lead to loss of balance homeostasis of animals, which leads to pathology and consequently impaired animal welfare. Future application of modern techniques of reproduction and DNA in animal breeding can increase the level of production, even faster than today, which can lead to more dramatic consequences for behavior, physiological and immunological characteristics. The election for more than production traits alone can not prevent such. Without knowledge of basic physiological processes in which genetic selection acts, the choice is essentially a black box technique. Knowledge of biological origin will 
offer the ability to understand, predict and prevent unwanted side effects of selection.

New challenges facing the sheep breeding of Serbia, stems from a political orientation toward membership in the European Union (Petrovic, 2005). New conditions for agriculture of the Republic of Serbia shall be established and reflected in the transition from centrally planned economies, where the greatest responsibility on the state apparatus, to a market where the center of the responsibility of the individual. The new integration processes (the WTO and the EU) will further change the economic conditions that will be reflected in the liberalization of agriculture, and therefore require even greater competitiveness. Increasing competitiveness is reflected in rising living standards over time and it can increase investment both in equipment and new technologies and investments in knowledge. This implies that the sheep sheep breeding, the structure of farms, quality standards, marketing, education and training must be improved. Only by increasing the competitiveness of farmers from the Republic of Serbia can not survive and thrive in the highly competitive EU internal market.

\section{Conclusion}

Serbia has the resources and tradition in the sheep breeding. But the changes that took place last twenty years and the direction to the European Union, require a lot of knowledge and adaptations. Sustainable access to sheep production in Serbia and agriculture in general, seeks to strengthen family farms, protect and exploit natural resources. This can provide a good farmers' profit, improve the efficiency of the genetic potential of sheep and perform the restoration of natural and economic resources for future generations. With these goals in mind, the sustainable production of cheap food for sheep, controlled grazing, integrated management of diseases are necessary steps in this way. Many small farmers that are dominant in Serbia need to increase economical viability and find alternative marketing strategies, including the fostering of local or regional markets. Based on the fact that Serbia has about 1.5 million sheep and preserved natural environment, there are preconditions for successful development of sustainable sheep and avoid the risks such negative effects of modern technology.

\section{Acknowledgment}

This study is realized by financial support of Ministry of Education and Science, Republic of Serbia, TR 31053. 


\title{
Mogućnosti i izazovi održivog razvoja ovčarstva Srbije
}

\author{
M. P. Petrović, M. M. Petrović, D. Ružić-Muslić, V. Caro Petrović, N. Maksimović, \\ Z. Ilić, S. Vučković
}

\section{Rezime}

Ovaj rad analizira sadašnje stanje ovčarstva u Srbiji i daje smernice za održivi razvoj u budućnosti. On takođe raspravlja o izazovima modernog doba koji mogu uticati na održivost ovčarske proizvodnje. Srbija danas raspolaže sa nešto manje od 1,5 miliona ovaca. U pogledu rasne strukture, većinu čini pramenkalokalne autohtone ovce, dok preostalih 15-20\% su: Cigaja, Merinolandschaf, Ile de France, Pirotska oplemenjena, novo proizvedena Mis ovca, i druge manje važne populacije, kao i melezi sa inostranim rasama. Međutim, zbog intenzivnog procesa industrijalizacije, od druge polovine dvadesetog veka do danas postoji trend smanjenja seoskog stanovništva i pražnjenja sela, što je rezultiralo smanjenjem farmi, tako da je broj ovaca u poslednje dve decenije opao za oko 30\%. Najveći pad broja ovaca registrovan je tokom devedesetih. Posle stabilizacije, veliki pad u broju ovaca je usledio 2010. godine za $6 \%$ u odnosu na 2008. godinu. Genetsko unapređenje je poslednjih decenija znatno povećalo nivo proizvodnje svih vrsta domaćih životinja. Međutim, životinje selekcionisane za visoku i efikasnu proizvodnju izloženi su većem riziku. Ovo se prvenstveno odnosi na fiziološke i imunološke probleme, ali bi se generalno moglo reći da je sve to dovelo do narušavanja harmonije između organizma i sredine i posledica na molekularnom nivou. Održivi razvoj ovčarstva Srbije mora imati u vidu ovu realnost. Novi izazovi sa kojima se suočava ovčarstvo Srbije, proističu i iz političke orijentacije ka članstvu u Evropskoj uniji. Zbog svih pomenutih razloga ovčarstvo Srbije mora naći svoje pravo mesto u svetlu novih izazova.

\section{References}

DARCY J.B (1995): Sheep Management and Wool Technology. UNSW Press. DE VRIES F., HAMANN H., DISTL O. (2004): Estimation of genetic parameters in German meat and milk sheep breeds. Züchtungskunde, 76, 2, 117-126.

HANFORD K.J., VAN VLECK L.D., SNOWDER G.D. (2002): Estimates of genetic parameters and genetic change for reproduction, weight,and wool characteristics of Columbia sheep. J. Anim. Sci. 80, 3086-3098.

HANFORD K.J., VAN VLECK L.D., SNOWDER G.D. (2003): Estimates of genetic parameters and genetic change for reproduction, weight, and wool characteristics of Targhee sheep. J. Anim. Sci., 81, 630-640. 
HANFORD K.J., VAN VLECK L.D., SNOWDER G.D. (2005): Estimates of genetic parameters and genetic change for reproduction, weight, and wool characteristics of Rambouillet sheep. Small Rumin.Res., 57, 175-186.

MASON J. (2003): Sustainable Agriculture. Landlinks Press, 208 p.

MEKIC C. (1994): Investigation of reproductive and productive traits of Ile de france breed of sheep. Doctoral dissertation, University of Belgrade.

MEKIĆ C., TRIFUNOVIĆ G., PERIŠIĆ P., VUJIĆ R., PETROVIĆ P.M. (2008): Uticaj farme, pola i tipa rođenja na telesnu masu jagnjadi za vreme dojnog perioda kod sjeničke oplemenjene pramenke. Biotechnology in Animal Husbandry, 24, 137-142.

NEETESON A.M., WARKUP C., HALEY C., JUGA J., KNAP P., MONGET P., NORRIS A., HARVEST M., ROSATI A., SCHULZE V., STOLL J. (2006): Sustainable Farm Animal Breeding and Reproduction - A Vision for 2025. FABRE Technology Platform.

NOTTER D.R. (2001): Genetic evaluation systems and the U.S. sheep industry. The Shepherd, 46, 12, 18-19.

PETROVIĆ M.M. (2005): Livestock production in Serbia on way to European Union. Biotehnology in Animal Husbandry, 21, 5-6, 1-8.

PETROVIĆ P.M. (1992): Investigation of reproductive and productive traits of wirtemberg breed of sheep (merinolandschaf). Doctoral dissertation, University of Belgrade.

PETROVIĆ P.M. (2000): Genetic and improvement of sheep. Scientific Book, Belgrade, $365 \mathrm{p}$.

PETROVIC P.M. (2006): Creation of meaty sheep breed. Mis sheep. Institute for Animal Husbandry, Belgrade, $43 \mathrm{p}$.

PETROVIC P.M. (2007): Sustainable sheepbreeding. Institute for Animal Husbandry, Belgrade, $256 \mathrm{p}$.

PETROVIC P.M., RUZIC-MUSLIC D., ZUJOVIC M., CARO-PETROVIC V., PERISIC P. (2008): Investigation of genetic and paragenetic parameters of milk production in sheep. Egyptian Journal of Sheep and Goat Sciences, 3, 1, 1-6.

PETROVIĆ P.M., SRETENOVIĆ LJ., ALEKSIĆ S., RUZIC.MUSLIĆ D., MAKSIMOVIĆ N. (2008): Application of sustainable systems for milk production on small farms. Biotechnology in Animal Husbandry, 5-6, 71-76.

PETROVIĆ P.M., SRETENOVIĆ LJ., RUŽIĆ MUSLIĆ D., MEKIĆ C., MAKSIMOVIĆ N. (2009): The effect of the level of application of selection and breedeng criteriaas factor of sustainable sheep production on productive traits of sheep in extensive rearing system. Biotechnology in Animal Husbandry,25, 12,111-119.

PETROVIĆ P.M., RUŽIĆ-MUSLIĆ., MAKSIMOVIĆ N. (2009): Evaluation of genetic potential of sheep in different production systems. Biotechnology in Animal Husbandry, 25, 5-6, 421-429. 
PETROVIĆ P.M., RUŽIĆ MUSLIĆ D., MAKSIMOVIĆ N., MEMIŠI N. (2009): Effect of environmental and paragenetic factors on birth mass variability of Mis sheep population. Biotechnology in Animal Husbandry, 25, 3-4, 213-219.

PETROVIC M.P., RUŽIC-MUSLIC D., ALEKSIC S., MAKSIMOVIC N. (2010): Investigation of production traits of the most important sheep breeds in Serbia. Journal of Mountain Agriculture on the Balkans, 13, 2, 356-366.

SAFARI E., FOGARTY N.M., GILMORE A.R. (2005): A Review of genetic parameter estimates for wool, growth, meat and production traits in sheep. Livestock Production Science, 92, 271-289.

SERRADILLA J.M. (2002): New techniques for sustainable sheep and goat production. Course material. Tunis, 12, 9-20.

SNOWDER G.D. (2002): Composite trait selection for improving lamb production. Sheep Goat Res. J., 17, 42-48.

TABERLET P., COISSAC E., PANSU J., POMPANON F. (2011): Conservation genetics of cattle, sheep, and goats .Comptes Rendus Biologies, 334, 3, 247-254.

TENEVA A. (2009): Molecular markers in animal genome analysis. Biotechnology in Animal Husbandry, 25, 5-6,1267-1284.

TENEVA A., PETROVIC P.M. (2010): Application of molecular markers in livestock improvement. Biotechnology in Animal Husbandry, 26, 3-4, 135-154.

UGARTE E. (2007): The breeding program of Latxa breed. Biotechnology in Animal Husbandry, 5-6, 97-111.

WELLS A., GEGNER L., EARLES R. (2000): Sustainable sheep production. ATTRA Publication IP-102. 